\title{
First record of Glycera guatemalensis and G. sphyrabrancha (Annelida: Glyceridae) from Western Mexico
}

\author{
María Elena García-Garza ${ }^{1}$, Iliana Torres-Manríquez ${ }^{1}$, María Ana Tovar-Hernández ${ }^{1} \&$ \\ Jesús Angel de León-González ${ }^{1}$ \\ 1. Universidad Autónoma de Nuevo León, Facultad de Ciencias Biológicas, Laboratorio de Biosistemática, San Nicolás \\ de los Garza, N.L. 66455, México; jesus.deleongn@uanl.edu.mx
}

Received 24-VIII-2018. Corrected 24-V-2019. Accepted 30-VI-2019.

\begin{abstract}
Introduction: Glycerides, commonly called "blood worms", are relatively thin polychaetes that reach considerable sizes. They have been reported for all the seas of the world from the intertidal zone to abyssal depths. Objective: Evidence the presence of two species of Glycera for the littorals of the Mexican Pacific. Methods: An analysis of the glycerides of the Pacific coast of Mexico was carried out, finding two species that were collected, one of shrimp trawl at a depth of 18 meters off Puertecitos, Baja California, as well as by manual sampling in the intertidal zone of Concepción Bay, Baja California Sur in the Gulf of California. For their taxonomic determination, morphological characters of greater relevance for their identification were examined, such as jaws, aileron shape, parapodia, chaetae, and the type of pharyngeal papillae. Results: We diagnosed and schematized Glycera guatemalensis Böggemann \& Fiege, 2001 and Glycera sphyrabrancha Schmarda, 1861. Conclusions: Glycera guatemalensis described for Guatemala and Glycera sphyrabrancha described for Jamaica, are recorded for the first time for the Gulf of California.
\end{abstract}

Key words: Glyceridae, G. guatemalensis, G. sphyrabrancha, new records, Gulf California.

García-Garza, M. E., Torres-Manríquez, I., Tovar-Hernández, M. A., \& de León-González, J. A. (2019). First record of Glycera guatemalensis and G. sphyrabrancha (Annelida: Glyceridae) from Western Mexico. Revista de Biología Tropical, 67(S5) Suplemento, S63-S69.

Glyceridae Grube, 1850 is a polychaete family whose species have predatory habits, these can be found associated to soft-bottom substrates, and are called "bloodworms" commonly. There are 87 valid species belonging to five genera (Read \& Fauchald, 2019). The first report of a glycerid for western Mexico was made by Moore (1911), who describes Glycera branchiopoda from Collnet basin, NW Baja California Peninsula, at 1

$400 \mathrm{ft}$ depth. Posteriorly, Glyceridae has been treated by several authors whom report 20 species of genus Glycera: G. americana Leidy, 1855, G. branchiopoda Moore, 1911, G. brevicirris Grube, 1870, G. capitata Ørsted,
1843, G. dibranchiata Ehlers, 1868, G. lapidum Quatrefages, 1866, G. longipinnis Grube, 1878, G. oxycephala Ehlers, 1887, G. pacifica Kinberg, 1865, G. papillosa Grube, 1857, G. profundi Chamberlin, 1919, G. prosobranchia Boggeman \& Fiege 2001, G. robusta Ehlers, 1868, G. tenuis Hartman, 1944, G. tesselata Grube, 1863, G. sphyrabrancha Schmarda, 1861, and genus Hemipodus: $H$. armata Hartman, 1950, H. californiensis Hartman, 1938, H. pustulata (Friedrich, 1956), $H$. simplex (Grube, 1857) (Chamberlin, 1919; Hartman, 1940, 1950, 1963; Rioja, 1941, 1947; Treadwell, 1942; Fauvel, 1943; Berkeley \& Berkeley, 1950; Reish, 1963, 1968; 
Fauchald, 1972; Kudenov, 1975, 1980; Blake, 1985; Salazar-Vallejo, de León González, \& Chávez-Comparán, 1990; Hernández-Alcántara \& Solís-Weiss, 1993, 1999; Böggemann, 2002; Hernández-Alcántara, Tovar-Hernández, \& Solís-Weiss, 2008; Díaz-Castañeda, de León-González, \& Solana-Arellano, 2014; Villalobos-Guerrero \& Molina-Acevedo, 2014; Prado-Navarro, Díaz-Castañeda, Leija-Tristán, \& de León-González, 2016; Cuéllar-Mercado, Hernández-Alcántara, \& Solís-Weiss, 2019). The aim of this study is to describe and illustrate species of Glyceridae previously unknown from western Mexico.

\section{MATERIAL AND METHODS}

The examined material is the result of a series of sampling efforts, from the intertidal zone to the Continental Shelf of the upper Gulf of California, as well as a monitoring program in the shore of the main bays. Glycerids were sampled on intertidal and associated to a shrimp trawl at $30 \mathrm{~m}$ depth. Specimens were fixed in formaldehyde and preserved in $70 \%$ ethanol. The material was deposited in the Polychaete Collection of the Universidad Autónoma de Nuevo León (NL-INV-0002-05-09), México.

\section{SYSTEMATIC ACCOUNT}

Glyceridae Grube, 1850

Glycera Savigny in Lamarck, 1818

\section{Glycera guatemalensis}

Böggemann \& Fiege, 2001

(Fig. 1)

Glycera lancadivae.- Berkeley \& Berkeley, 1939:334 (fide Böggemann, 2002, non Schmarda 1861).

Glycera guatemalensis Böggemann \& Fiege, 2001:35; figs. 4, 8g-h, 10; Böggemann, 2002: 43-44, Figs. 31-33.

Examined material: Two specimens (UANL 8128). Puertecitos, Baja California,
Gulf of California, $30^{\circ} 24^{\prime} 46^{\prime \prime} \mathrm{N}, 114^{\circ} 38^{\prime} 01^{\prime \prime}$ W, 18 m, December 28, 1985, col. Eulogio Reyes, by catch in shrimp trawl.

Description: Both specimens complete, longer specimen $171 \mathrm{~mm}$ long, $7.5 \mathrm{~mm}$ wide, with 318 chaetigers; shorter specimen $166 \mathrm{~mm}$ long, $6.8 \mathrm{~mm}$ wide and 287 chaetigers. Segments bi-annulate from chaetiger 15. Conical prostomium with 10 rings (Fig. 1A). Pharynx completely everted, 37 and $20 \mathrm{~mm}$ long, respectively. Two types of papillae arranged irregularly along surface: 1) mostly conical with a straight, median, longitudinal ridge (Fig. 1D); 2) other isolated, globular, without ridges (Fig. 1C). Pharynx armed with four terminal jaws and ailerons with a deeply incised base, outer ramous slightly pointed (Fig. 1B).

First two parapodia uniramous, following parapodia biramous. Parapodia with two slender triangular to digitiform prechaetal lobes, anterior ones with both lobes of about same length (Fig. 1E-H); mid-body and posterior parapodia with notopodial lobes longer and slightly wider than neuropodial ones (Fig. 1I-M). Postchaetal lobes shorter, rounded, neuropodial slightly longer than notopodial one. Dorsal cirri conical to oval from chaetiger 3, inserted on parapodial basis (Fig 1E-M). Ventral cirri slender, triangular to digitiform, on anterior parapodia slightly longer than post-chaetal neuropodial lobe, on mid-body and posterior parapodia, almost longer than pre-chaetal neuropodia (Fig. 1I-M). Branchiae absent.

Remarks: The unique morphological difference between the Mexican and Guatemalan specimens is that the Mexican specimens present anterior dorsal cirri nearly digitiform, middle-anterior ones oval, and middle-posterior and posterior ones conical. Guatemalan specimens have anterior dorsal cirri oval, middle ones conical and posterior ones oval. However, that variation may due to ontogenetic events, our specimens are twice longer than type specimens. 


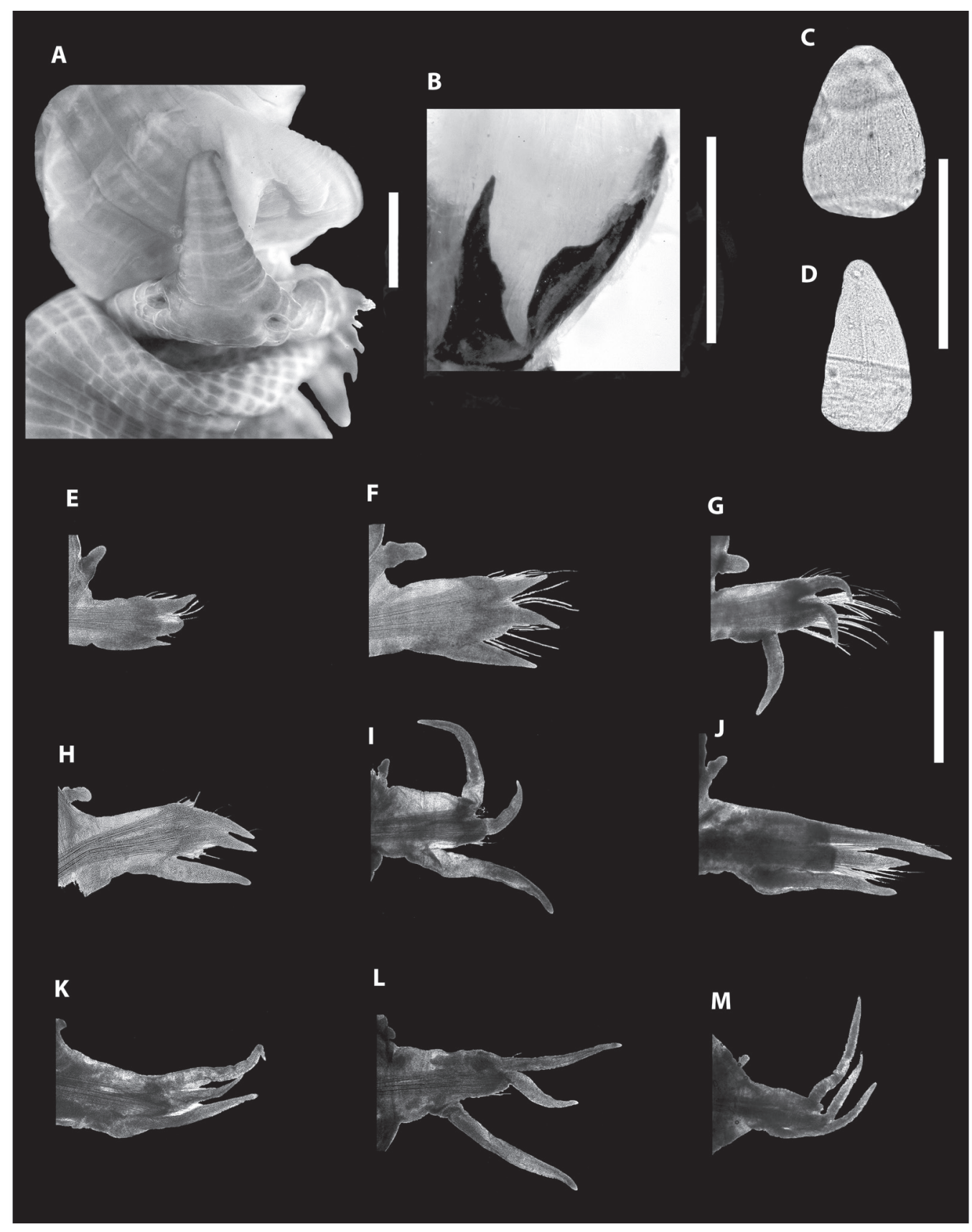

Fig. 1. Glycera guatemalensis A. Anterior end, dorsal view; B, Aileron; C, Globular proboscidal papilla; D, Conical proboscidal papilla; E Chaetiger 5; F, Chaetiger 11; G, Chaetiger 20, H, Chaetiger 30; I, chaetiger 70; J. Chaetiger110; K, Chaetiger 215; M, Chaetiger 300. (Scale bars: A-B=1 mm; C-D $=0.001 \mathrm{~mm}$; E-M=1 mm). 
Distribution: This species was previously known by the type locality, San José, Guatemala, at $18 \mathrm{~m}$ depth (Böggemann, 2002). It is first report for the Gulf of California.

\section{Glycera sphyrabrancha Schmarda, 1861}

(Fig. 2)

Glycera sphyrabrancha Schmarda, 1861: 96; Pl. 30, Fig. 240, texfigs. a-c; Böggemann, 2002: 42-43, Figs. 28-30.

Material examined: One specimen (UANL8129). Cocos beach, Concepción Bay, Baja California Sur, 264'39.1" N, 111'53'55.4" W, intertidal, April 01, 2011, Coll. MEGG and JALG.

Description: Specimen complete, $165 \mathrm{~mm}$ long, $3.76 \mathrm{~mm}$ wide, and 295 chaetigers. Segments bi-annulate with same size of annuli from chaetiger 10, anterior ones uni-annulate. Conical prostomium with 11 rings (Fig. 2A). Pharynx everted $15 \mathrm{~mm}$ long, with two types of papillae: 1) numerous digitiform papillae without ridges (Fig. 2C); 2) some isolated, oval to globular papillae, without ridges (Fig. 2D). Pharynx with four terminal jaws, ailerons with deeply incised base (Fig. 2B).

First two parapodia uniramous, following parapodia biramous. Two slender triangular to digitiform prechaetal lobes, on anterior parapodia, noto- and neuropodial prechaetal lobes subequal, middle and posterior parapodia with neuropodial prechaetal lobes slightly longer than notopodial ones. Postchaetal lobes rounded. Dorsal cirri from third parapodia, inserted slightly above parapodial base, digitiform with a slightly swollen dorso-basally, longer on anterior parapodia, diminishing in size from middle to posterior parapodia (Fig. 2 E-M). Ventral cirri triangular on anterior parapodia (Fig. 2 E-G), digitiform on middle body region (Fig. 2H-J) and slender on posterior parapodia (Fig. 2K-M). Branchiae non-retractile, simple, appear on chaetiger 15 near upper chaetal lobe; slightly triangular anteriorly (Fig. 2F), becoming digitiform from middle of anterior region, and best developed in middle body region (Fig. 2G-J), in all parapodia branchiae inserted basally.

Remarks: The original description and illustrations of $G$. sphyrabrancha by Schmarda (1861) are not clear; however, Böggemann (2002) analyzed and redescribed the holotype collected in Jamaica. Our specimen collected in the Gulf of California is morphologically similar to the type redescribed by Böggemann (2002), but varies slightly in the shape of the dorsal cirrus, being conical to oval in the holotype versus digitiform and swollen basally in our specimen. As in the previous species, these differences can be attributed to ontogeny.

Distribution. This species is distributed in tropical waters, from intertidal to $250 \mathrm{~m}$ depth: Georgia and Florida (USA), Gulf of Mexico, Caribbean Sea, Puerto Rico, Barbados, Panamá (both sides), South Africa, Arabian Sea, Bay of Bengal and Solomon Islands (Böggemann, 2002).

Ethical statement: authors declare that they all agree with this publication and made significant contributions; that there is no conflict of interest of any kind; and that we followed all pertinent ethical and legal procedures and requirements. All financial sources are fully and clearly stated in the acknowledgements section. A signed document has been filed in the journal archives.

\section{ACKNOWLEDGMENTS}

This research was funded by a grant provided by the Comisión Nacional para el Conocimiento y Uso de la Biodiversidad, CONABIO (Project H-029).

\section{RESUMEN}

Primer registro de Glycera guatemalensis y $G$. sphyrabrancha (Annelida: Glyceridae) para el oeste de México. Introducción: Los Glicéridos son llamados comúnmente "gusanos de sangre", son poliquetos relativamente delgados que alcanzan tallas considerables. Han sido 


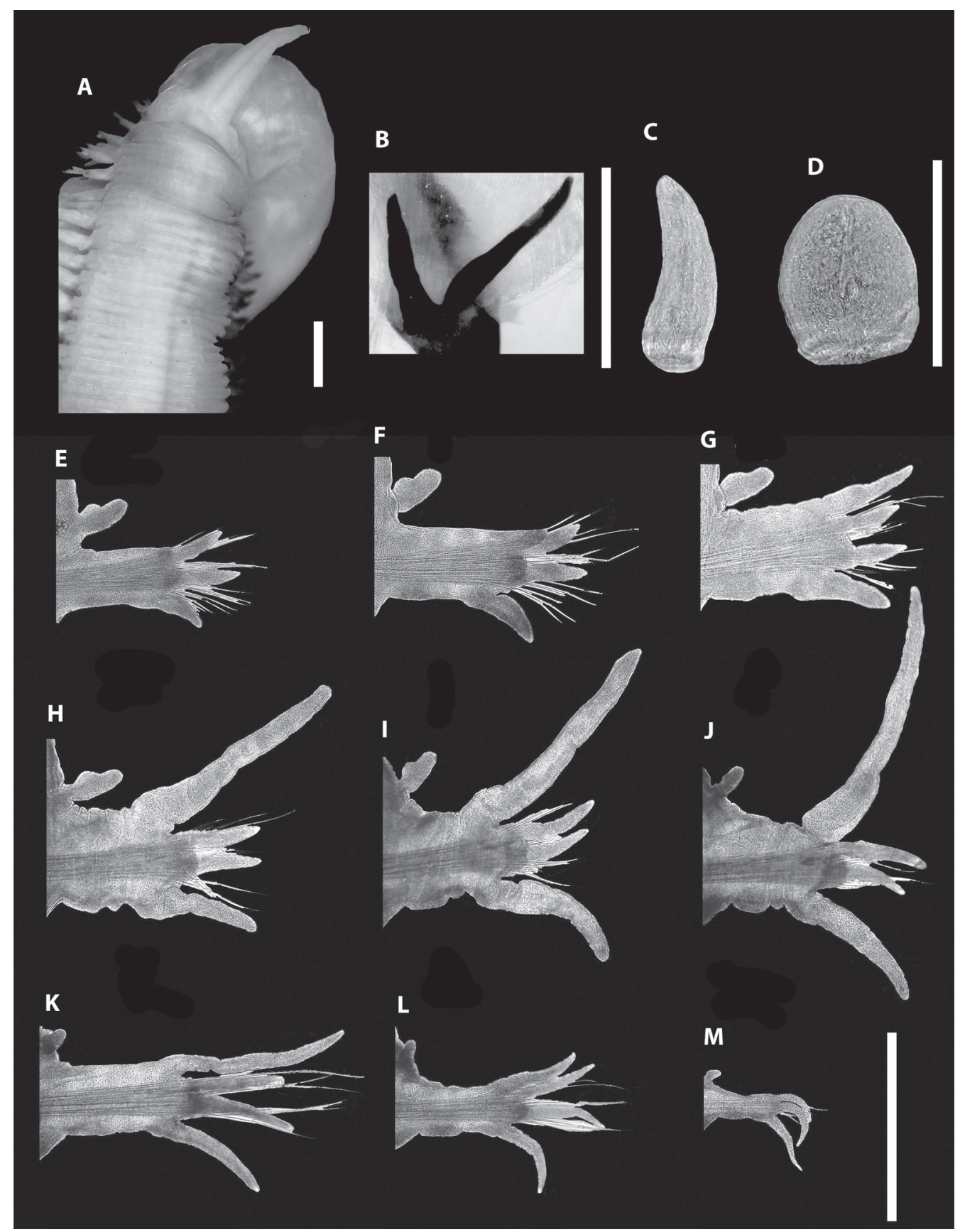

Fig. 2. Glycera sphyrabrancha A, Anterior end, dorsal view; B, Aileron; C, Conical proboscidial papilla; D, Globular proboscidial papilla; E, chaetiger 11; F, chaetiger 19; G, chaetiger 30; H, chaetiger 70; I, chaetiger 110; J, chaetiger 200; $\mathrm{K}$, chaetiger 249; L, chaetiger 280; M, chaetiger 290. (Scale bars: B-D front view; E-M posterior view; scale bars A-B = 1 $\mathrm{mm}, \mathrm{C}-\mathrm{D}=0.01 \mathrm{~mm}, \mathrm{E}-\mathrm{M}=1 \mathrm{~mm})$. 
reportados para todos los mares del mundo desde la zona de entremareas hasta profundidades abisales. Objetivo: Evidenciar la presencia de dos especies de Glycera para los litorales del Pacífico mexicano. Métodos: Se realizó un análisis de los glicéridos de la costa del pacífico de México, encontrando dos especies que fueron recolectadas, una de arrastre camaronero a una profundidad de 18 metros frente a Puertecitos, Baja California, así como mediante muestreo manual en la zona de entremareas de bahía Concepción, Baja California Sur en el golfo de California. Para su determinación taxonómica se examinaron los caracteres morfológicos de mayor relevancia para su determinación, como mandíbulas, forma del aileron, parapodios, setas, branquia, y tipo de papilas faríngeas. Resultados: En este trabajo se diagnostican y esquematizan Glycera guatemalensis Böggemann \& Fiege, 2001 y Glycera sphyrabrancha Schmarda, 1861. Conclusión: Glycera guatemalensis descrita para Guatemala y Glycera sphyrabrancha descrita para Jamaica, se registran por primera vez para el golfo de California.

Palabras clave: Glyceridae, G. guatemalensis, G. sphyrabrancha, nuevos reportes, Golfo de California.

\section{REFERENCES}

Berkeley, E., \& Berkeley, C. (1939). On a collection of Polychaeta, chiefly from the west coast of México. Annals and Magazine of Natural History, 3(Series 11), 321-346.

Berkeley, E., \& Berkeley, C. (1950). Notes on Polychaeta from the Coast of Western Canada. IV. Polychaeta Sedentaria. Annals \& Magazine of Natural History, 3 (Series 12), 50-69.

Blake, J. A. (1985). Polychaeta from the vicinity of deep-sea geothermal vents in the eastern Pacific. I: Euphrosinidae, Phyllodocidae, Hesionidae, Nereididae, Glyceridae, Dorvilleidae, Orbiniidae and Maldanidae. Biological Society of Washington Bulletin, 6, 67-101.

Böggemann, M. (2002). Revision of the Glyceridae Grube 1850 (Annelida: Polychaeta). Abhandlungen der Senckenbergischen Naturforschenden Gesellschaft Frankfurt am Main, 555, 1-249.

Böggemann, M., \& Fiege, D. (2001). Description of seven new species of the genus Glycera Savigny, 1818 (Annelida: Polychaeta: Glyceridae). Ophelia, 54(1), 29-49.

Chamberlin, R. V. (1919). The Annelida Polychaeta of the Albatross Tropical Pacific Expedition, 1891-1905. Memoirs of the Museum of Comparative Zoology, Harvard College, 48, 1-514.

Cuéllar-Mercado, D. M., Hernández-Alcántara, P., \& Solís-Weiss, V. (2019). Composition, richness and taxonomic diversity of Polychaete assemblages from La Paz Bay and adjacent oceanic areas of the Southern Gulf of California. Regional Studies in Marine Science, 28, 1-7.

Díaz-Castañeda, V., de León-González, J. A., \& SolanaArellano, E. (2014). Biodiversity of polychaetes assemblages in a highly productive lagoon located in Baja California Sur, Mexico. Proceedings of the Biological Society of Washington, 127(2), 406-422.

Fauchald, K. (1972). Benthic polychaetous annelids from deep water off western Mexico and adjacent areas in the eastern Pacific Ocean. Allan Hancock Monographs of Marine Biology, 7, 1-575.

Fauvel, P. (1943). Annélides polychètes de Californie recuiellies par L. Diguet. Mémoires du Muséum National d'Histoire Naturelle, Paris, 18, 1-32.

Grube, A. E. (1850). Die Familien der Anneliden. Archiv für Naturgeschichte, 16, 249-364.

Hartman, O. (1940). Polychaetous annelids, 2. Chrysopetalidae to Goniadidae. Allan Hancock Pacific Expeditions, 7, 173-287.

Hartman, O. (1950). Goniadidae, Glyceridae and Nephtyidae. Allan Hancock Pacific Expeditions, 15, 1-181.

Hartman, O. (1963). Submarine canyons of Southern California, 3. Systematics: polychaetes. Allan Hancock Pacific Expeditions, 27(3), 1-93.

Hernández-Alcántara, P., \& Solís-Weiss, V. (1993) New records of sedentariate Polychae- tous annelids from the continental shelf of the Gulf of California. Bulletin of Marine Science, 53 (3), 1027-1041.

Hernández-Alcántara P., \& Solís-Weiss V. (1999) Systematics and distribution of the polychaetes (Annelida: Polychaeta) from the sublittoral zone in the Gulf of California. Oceánides, 13, 25-38.

Hernández-Alcántara, P., Tovar-Hernández, M. A., \& SolísWeiss, V. (2008) Polychaetes (Annelida:Polychaeta) described from the Mexican Pacific: and historical review and an updated checklist. Latin American Journal of Aquatic Research, 36 (1), 37-61.

Kudenov, J. D. (1975). Errant polychaetes from the Gulf of California. Journal of Natural History, 9, 65-91.

Kudenov, J. D. (1980). Annelida: Polychaeta (Bristleworms). In: R. C. Brusca (Ed.). Common Intertidal Invertebrates of the Gulf of California. (2 ed., pp. 77-123). Tucson: University of Arizona Press.

Moore, J. P. (1911). The Polychaetous Annelids Dredged by U.S.S. "Albatros" off the Coast of Southern California in 1904: III. Euphrosinidae to Goniadidae. Proceedings of the Academy of Natural Sciences of Philadelphia, 63 (2), 234-318. 
Prado-Navarro, A., Díaz-Castañeda, V., Leija-Tristán, A., \& de León-González, J. A. (2016). Composición y estructura de las comunidades de poliquetos (Annelida) asociados a fondos blandos de la costa occidental de la peninsula de Baja California, México. Revista Mexicana de Biodiversidad, 87, 74-85.

Read, G., \& Fauchald, K. (Ed.) (2019). World Polychaeta database. Glyceridae Grube, 1850. Retrieved from http://www.marinespecies.org/aphia. php? $\mathrm{p}=$ taxdetails\&id=952 on 2019-04-17.

Reish, D. J. (1963). A quantitative study of the benthic polychaetous annelids of Bahia de San Quintín, Baja California. Pacific Naturalist, 3, 401-436.

Reish, D. J. (1968). A biological survey of Bahía de Los Angeles, Gulf of California, México, 2. Benthic Polychaetous Annelids. Transactions of the San Diego Society of Natural History, 15, 67-106.

Rioja, E. (1941). Estudios anelidológicos, 3. Datos para el conocimiento de la fauna de poliquetos de las costas mexicanas del Pacífico. Anales del Instituto de Biología, Universidad Nacional Autónoma de México, 12, 669-746.

Rioja, E. (1947). Estudios anelidológicos, 17. Contribución al conocimiento de los anélidos poliquetos de Baja California y Mar de Cortés. Anales del Instituto de
Biología, Universidad Nacional Autónoma de México, 18, 197-224.

Salazar-Vallejo, S. I., de León-González, J. A., \& ChávezComparán, J. C. (1990). Poliquetos (Annelida Polychaeta) de la Bahía de Manzanillo, con una clave ilustrada para lase species de Colima, México. Revista de Biología Tropical, 38(2A), 211-229.

Savigny, J. C (1818). Classe Neuvième. Les Annelids. (Annelides). In J. B. Lamarck (Ed.). Histoire Naturelle des Animaux sans Vertèbres, (5, pp. 274-374). Paris: Chez Deterville, chez Verdiere, Juillet.

Schmarda, L. K. (1861). Neue wirbellose Thiere beobachtet und gesammelt auf einer Reise um die Erde 1853 bis 1857. 1. Turbellarian, Rotatorien und Anneliden, 2, $1-164$.

Treadwell, A. L. (1942). Polychaetous annelids from Lower California and the Philippine Islands in the collections of the American Museum of Natural History. American Museum Novitates, 1172, 1-5.

Villalobos-Guerrero, T. F., \& Molina-Acevedo, I. C. (2014). Lista de especies y estado de conocimiento de los poliquetos (Annelida Polychaeta) de Sinaloa, Golfo de California. Boletín del Instituto de Oceanografia de Venezuela, 53(1), 79-109. 